\title{
EUROPEAN FAMILY LAW: PROBLEMS OF FORMATION
}

\section{Hlynyanaya K. M.}

\section{INTRODUCTION}

The term "space of freedom, security and justice" (hereinafter referred to as the "Space") first appeared in the 1997 Amsterdam Treaty. In essence, this refers to the gradual smoothing of differences, harmonization, and future merging of the law enforcement systems of the EU member states ${ }^{1}$.

Certain difficulties arise when trying to formulate such fundamental concepts as, for example, "European private law", "European family law", "unification and harmonization of European family law".

In the classical interpretation of Roman continental law, it is customary to separate public law and private law. In the continental (European) system of law, the distinction between private and public law does not reflect industry specifics, but indicates the presence of two relatively independent branches of legal regulation that have significant differences in the nature of the impact on public relations. Also, in a number of countries of the continental system of law, a dualistic system of private law operates (private law is divided into civil and commercial law, respectively, the civil and commercial codes are in force).

In addition to civil law, the private law system also identifies industries such as family, inheritance and private international law.

In the literature, there is also such a thing as "European private law" (in German literature Europaeisches Privatrecht, in French droit prive europeen, in English-language European private law).

The program "community integration" has become a fundamental milestone in the history of private law, defining the main directions of its further evolution: the development of unified and harmonized norms of European private law and the development of European legal science. As you know, initially harmonization and unification took place in the areas of commercial law and related fields of civil law.

As a result of European integration and the removal of restrictions on the free movement of people in the European Union, one of the most specific characteristics of their personal lives is gradually changing: an increase in the number of families whose members are either citizens of different EU countries, or when one of the family members is a citizen of an EU country or have several citizenships.

${ }^{1}$ Бирюков М.М. Европейское право: до и послеЛиссабонского договора. М.: Статут, 2013. C. $105-132$. 
We must also not forget that family law, unlike any other branch of law, affects not only the private interests of individuals, but also ensures the relationship between the public and private interests of society. No society can maintain the rule of law without establishing rules for the relationship of people, without fixing restrictions and prohibitions. This is precisely the reason why in a number of states it is believed that family law, or at least part of it, is regulated by public law.

Naturally, there is a need for legal regulation of the conclusion of crossborder marriages, marital and parental legal relations. A particularly urgent need for such legal regulation arises in situations where such families break up, and family members, including children, live in different states.

The cross-border context determines the specifics of family relationships and caring. ${ }^{2}$ Naturally, each state, nation, country has its own unique national heritage, on which the norms of family law are based. The complexity of legal regulation lies in the fact that family relations with the participation of foreigners are immediately associated with two, and sometimes several, states, and, accordingly, with two or more legal systems, often solving marriage and family issues in different ways.

\section{Characteristics of European Family law}

Family law of every European country has its own national characteristics. On the one hand, this allows European nations to preserve their family traditions and culture, and on the other hand, it makes it difficult to fully exercise the rights of individuals in family relations in families with a foreign element when changing citizenship or country of residence.

Until recently, family law, thanks to the so-called "cultural restrictions", remained almost completely outside the scientific comparative legal study. In the scientific literature there is the concept of "cultural heritage of individual countries"3. According to this concept, the cultural and historical diversity of family traditions, the lack of common family values and goals are an insurmountable obstacle to the unification of family law. So, Otto Can-Freund speaks negatively about the idea of harmonizing the family law of the EU member states, considering such an idea a "hopeless issue". A skeptical attitude to the formation of a single family law for EU member states is based on the scientific works of scientists. In science, the prevailing opinion was that institutions and categories of family law are particularly susceptible to

2 Zechner M. Informaali hoiva sosiaalipoliittisessa kontekstissa. Acta Universitatis Tamperensis. Tampere: Tampere University Press, 2010.

${ }^{3}$ Guilherme de Oliveira Um direito da família europeu? Play it again... Europe! in "Um código civil para a Europa”. Coimbra: Coimbra Editora, 2002. P. 117-126. 
moral, religious, political and psychological effects, and since historically, racially, socially and religiously, family values differ from one country to another, family law in these countries is different from another noninterconnected legal systems.

Ole Lando, the "father" of the first harmonization project, made a statement in 2006: "Family legal acts of the EU countries reflect the national character, dominant religion, traditions, family issues that are related to the economic and social conditions of each country." For these reasons, Ole Lando thought that there could never be a convergence of family laws and, in particular, laws on divorce.

So, for quite a long time it was believed that family law could not be unified for all EU member states, since there is a factor of cultural restrictions.

However, as the lack of uniformity in the field of private law creates difficulties for the development of free movement of goods, services and capital, so the absence of a unified family law creates difficulties for the free movement of people and their creation of a family. After all, people cannot predict the legal consequences of their family acts and acts when moving from one EU country to another, as well as when they enter into family relations with a person who is a citizen of another EU state.

Family law affects the very essence of people's daily lives, like no other area of law does. Each person throughout his life in one way or another becomes the subject of family law.

The large differences between the national legal systems of the EU countries prevent the obtaining of a truly common European identity in the form of European citizenship and the formation of a comprehensive European legal space. Specific problems of legal regulation of a cross-border family include differing legal systems of states, as well as problems associated with distances and movements of family members, the resolution of which is, as a rule, within the competence of law enforcement agencies.

Such legal issues include, for example, issues:

- determination of the jurisdiction of the court when applying for the dissolution of marriage;

- the legislation of which state of the valley will be applied in resolving family disputes;

- fulfillment of maintenance obligations with a foreign element;

- realization and protection of such rights as the right to communicate and the right to reside with a child.

And although the problems of unification of family law did not initially attract attention and, accordingly, were not regulated in the Constituent Agreements, EU rulemakers sent EU member states along the path of mutual recognition and enforcement of court decisions. Of particular note is 
Article 67 of the Lisbon Treaty, which states that "the EU facilitates access to justice, in particular by using the principle of mutual recognition of judicial and extrajudicial decisions in civil matters".

Despite the ever-changing views of society on the institution of the family and its forms, the fundamental foundations of its legal regulation remain unshakable. Many legal concepts, such as marriage are akin to sacrament, the indissolubility of marriage or the exclusion of illegitimate children from family members have been developed for a long time by canon law. With changes in the mentality of society, ideological pluralism, it is increasingly difficult to apply these concepts, but they persist. Moreover, it is obvious that a number of reforms of family legislation carried out in one country take root in society, sooner or later other states will go for such reforms. For example, the right to divorce during the life of the spouses. In 1970, divorce was allowed in Italy, in 2011 in Malta. In the past few years, family law has increasingly become the subject of comparative legal research, law, and harmonization.

The accumulated experience of EU cooperation in cross-border civil matters indicates that European legal acts and mechanisms can be more effectively implemented for the benefit of citizens and society, if there is more: understanding and mutual trust between practicing lawyers in different EU countries; knowledge of EU legislation and developed legal instruments for cooperation; a consistent understanding of EU law (necessary to ensure proper and uniform application in national cases).

\section{The subject, function and method of European family law}

Traditionally, the norms of family law of any legal system regulate all the main varieties of family relations, primarily between spouses (former spouses), parents and children, other relatives.

The subject of European family law adheres to established traditions. However, in such family relationships there should be a European element complicating the mechanism of their legal regulation.

As the subject of legal regulation of European family law, it is necessary to consider: property relations of spouses and persons in partner unions, family rights of minors and their protection, maintenance relations, legal relations of parents and children, etc. However, these relationships must be complicated by the cross-border aspect,

The presence in the legal relationship of the European element can find expression, firstly, in its subjective composition, when the participant (both participants) of the legal relationship is a citizen (s) of different EU states. Secondly, the European element can be seen in cases where the legal fact that determines this or that family-legal state takes place outside the territory of 
the state, but within the EU. Thirdly, when family members who are citizens of one EU state reside in the territory of another.

It should be borne in mind that in the field of family relations, the possibility of cross-border conflicts is quite high ${ }^{4}$.

As a research method should use the method of comparative law. The method of comparative law is a way of knowing the legal systems of various states by comparing the same state and legal institutions, their basic principles and categories. It is with this method that it is possible to identify the common features of family law that are inherent in all countries of the European Union, to determine how, in which countries certain relations are regulated, and whether consensus is reached on legal issues.

The purpose of the study should be to study:

a) what methods are used in various legal systems in order to achieve equality between men and women, whether in marriage or common-law marriage, in relation to the property rights of these persons;

b) the rights and interests of minors and their protection;

c) national rules for regulating family rights in individual countries and the general principles for regulating family relations inherent in all EU countries (or at least the majority), identifying their advantages and disadvantages.

The influence of the developed concepts, principles, traditions of European norms on the national family law of the EU member states is considered as a necessary prerequisite for harmonization and unification of the EU family law.

European Family Law has the following functions:

- ideological - serves as a model for national legal systems;

- regulatory - allows you to regulate family relationships with the European element;

- preventive - eliminates conflicts of law of national systems of several EU countries, allowing participants in family relations and state bodies to decide on the choice of law.

\section{Sources of legal regulation of European family law}

The legal framework for regulating family relations with the European element is complex, multi-level in nature, it includes material and conflict norms contained in multilateral and bilateral international treaties, conventions, regulations, and domestic law.

${ }^{4}$ Kokkini-Iatridou D, et al. Een inleiding tot het rechtsvergelijkende onderzoek. Deventer, 1988. P. 128-188. 
Among the special international legal sources of a global nature, containing unified norms of substantive law, are the 1980 Convention on the Civil Aspects of International Child Abduction, the Hague Convention on the International Procedure for the Collection of Alimony for Children and Other Forms of the Family, and the Law Protocol, applicable to maintenance obligations "2007.

Among the special sources at the regional level are a number of conventions developed by the Council of Europe, in particular:

- Convention on the legal status of children born out of wedlock 1975;

- Convention on the Law Applicable to Alimentary Obligations in favor of Children of 1956;

- The 1958 Convention on the Recognition and Enforcement of Decisions in Cases of Maintenance Obligations for Children;

- Convention on Jurisdiction, Applicable Law and Recognition of Adoption Decisions, 1965;

- Convention on the Recognition of Divorces and Judicial Separation Decisions of 1970;

- Convention on the Law Applicable to Maintenance Obligations of 1973;

- Convention on the Law Applicable to Spouses' Ownership Regimes of 1978 ;

- Convention on the conclusion and recognition of the validity of marriages 1978;

- Convention on Jurisdiction, Applicable Law, Recognition, Enforcement and Cooperation with respect to Parental Responsibility and Measures for the Protection of Children, 1996

The most important sources of European family law are:

- Council Regulation (EU) No 2201/2003 of November 27, 2003 on jurisdiction in EU law of the provisions of the relevant Convention;

- Council Regulation (EU) No 1259/2010 of December 20, 2010 on the law applicable in the event of divorce or separation of spouses by a court decision (Rome III), which entered into force on June 21, 2012;

- Regulation of the European Council No. 4/2009 "On jurisdiction, applicable law, recognition and enforcement of decisions, as well as cooperation in the field of maintenance obligations".

There is no doubt that the decisions of the European Court of Human Rights (hereinafter - the ECHR) are crucial in discussing the harmonization and unification of the legislation of the EU countries. Thanks to the decisions of the ECHR, cases related to the violation of Art. 8 of the Convention on the Rights and Freedoms of Man and Citizen (hereinafter - the Convention), "The Right to Respect for Private and Family Life", it is possible to protect a wide variety of family rights, the borders of which are constantly expanding. 
Moreover, almost all the problems that arise in the practice of national courts for the protection of family rights are also developed in the decisions of the ECHR. Indeed, the decisions of the ECHR are binding on the administration of justice in all countries ${ }^{5}$.

So the German Constitutional Court stated: "At the level of domestic law, the provisions of international agreements are not considered directly applicable... and, like the generally recognized norms of international law..., they do not have the status of constitutional norms. The fundamental law undoubtedly follows the classical idea that the relation of public international law and domestic law is the relation of two different legal spheres.... The fundamental law seeks to integrate Germany into the legal community of peace-loving and free states, but does not renounce the sovereignty ultimately concluded in German constitution.... The law of international treaties applies at the domestic level only when it is incorporated into the internal legal system in an appropriate form and in accordance with substantive constitutional law, "the Constitutional Court emphasized ${ }^{6}$.

Accordingly, the courts are obliged to comply with and apply the Convention (it was duly ratified), but its violation does not in itself constitute a ground for complaint to the Constitutional Court. Moreover, there may be situations where the rights provided by the Convention conflict with the constitutional rights of others. The Constitutional Court emphasized that in the sense of domestic law, the Constitution, in principle, takes precedence over international obligations: in exceptional cases (ausnahmsweise), the legislator may deviate from the requirements of international treaties in order to avoid violation of fundamental constitutional principles.

Notwithstanding the foregoing, the Constitutional Court has recognized that the Convention and the practice of the ECHR are essential in German constitutional law. Namely, they should be "taken into account" when interpreting the provisions of national law, including the norms of the most basic law.

If the ECHR has recognized a law or a court ruling contrary to the Convention, the state is obliged to eliminate the violation. Accordingly, all state bodies are obliged to take measures within their competence to create a legal situation that meets the requirements of the Convention. This also applies to the courts. They are obliged to "take into account" (Berücksichtigungspflicht) the provisions of the Convention and the decisions

\footnotetext{
${ }^{5}$ Гармаш, А., Суслова, И. Защита прав детей в Европейском суде // ЭЖ-Юрист. М.: Изд. Экономическая газета, 2012. № 31. С. 15.

${ }^{6}$ Будылин С. Дело Гѐргюлю: Германия выбирает мир с ЕСПЧ / Режим доступа: https://zakon.ru/blog/2013/11/18/delo_gyorgyulyu_germaniya_vybiraet_mir_s_espch
} 
of the ECHR when interpreting national law, especially in the case of a reexamination of the case on which the ECHR has spoken. At the same time, however, priority provisions of national law should not be violated.

"Administrative bodies and courts cannot get rid of constitutional duties and the binding force of law and law (Gesetz und Recht)..., referring to the decision of the ECHR. However, the law also provides for the obligation to take into account the guarantees of the Convention and the decisions of the ECHR as part of a methodologically sound interpretation of the law. Both the refusal to take into account the decision of the ECHR, and the straightforward "enforcement" (Vollstreckung) of this decision, contrary to the law of a higher rank, can thus violate fundamental rights in combination with the rule of law (Rechtsstaatsprinzip), "concludes the Constitutional Court.

This is especially true for areas of law, such as family law, which themselves have the goal of balancing the fundamental rights of various individuals (father, son, foster family, etc.). The task of national courts is to carefully integrate the decision of the ECHR into the relevant field of law.1

The Court of Justice of the European Communities ensures that legislation interprets and applies fundamental treaties. In accordance with the Lisbon Treaty, it consists of the European Court, the court of first instance and specialized courts.

The Court of Justice of the European Communities has two crucial functions:

- verification of compliance of instruments of European bodies and national governments with treaties (legal proceedings in cases of violation of rights, inaction, invalidation);

- the issuance of court orders in response to requests from national courts with an interpretation or assessment of the legality of certain provisions of EU legislative acts (recommendations for preliminary orders).

The European Court of Justice in Luxembourg has established that the "communitarian integration method" program established by the EU Treaty also extends to family law.

It is believed that the role of European family law is mainly related to ensuring the implementation in one state of the decision adopted in another, as well as in determining which country has jurisdiction to consider a particular case. It is assumed that European family law does not have the ability to establish substantive law, for example, who has the right to guardianship or access.

\section{European Commission on Family Law}

A new organization created by the European Union has appeared on the international "market" of legal organizations, which are traditionally dominated by the National Conference of State Commissioners for the 
Unification of State Laws (NCCUSL) and the American Law Institute (ALI). Previously, there was no analogue to acts issued by NCCUSL or model acts and principles developed by ALI in European law. And this legal vacuum in September 2001 was filled by the European Commission on Family Law, thanks to the private initiative of scholars from 22 countries of the European Union, experts in the field of family law and comparative law. The European Commission on Family Law (hereinafter - CEFL) was established.

Over time, it became clear that the normal functioning of the EU is impossible without the unification and harmonization of family law. Significant differences in the national laws of European countries governing the institution of the family greatly complicate the process of regulating crossborder family relations. Since the beginning of the 1990s, European legal conferences have been held focused on a comparative analysis of the family law of the EU states.

They raise relevant issues in the field of national family law of the EU states, international family and inheritance law by the Council of Europe ${ }^{7}$. Of particular note is the Hague Conference on Private International Law ${ }^{8}$. At these conferences, conventions, resolutions and principles of family law are developed ${ }^{9}$.

The European Commission on Family Law is an independent organization and consists of two groups: an organizing committee and an expert group. The organizing committee forms an expert group and coordinates the work of CEFL. Members of the organizing committee are simultaneously members of the expert group ${ }^{10}$.

The expert group is composed of experts in the field of family and comparative law from most member states of the European Union with the involvement of experts from other European countries, such as Norway and Switzerland.

The European Commission on Family Law has initiated a research project aimed at cross-border cooperation in resolving family conflicts that arise between family members - citizens of the European Union.

The main objective of the CEFL is to establish the principles of European family law and develop the most effective institutions and means of harmonization and unification of family law in the European Union. The principles are considered as the most suitable means for harmonizing family laws in Europe, since when developing them, the CEFL carried out an in-

\footnotetext{
${ }^{7}$ D. Schwab et al. (eds.), Entwicklungen des europäischen Kindschaftsrechts, 1994.

${ }^{8}$ Der Schutz der Familienwohnung in europäischen Rechtsordnungen, 1995.

9 Familiäre Solidarität- die Begründung und die Grenzen der unterhaltspflicht unter Verwandten im europäischen Vergleich, 1997.

${ }^{10}$ Family law and children's rights. Режим доступа: at http://www.coe.int.
} 
depth and comprehensive comparative study on the one hand, and when they were approved, they were guided by the principle of expediency. We believe that the developed basic principles of legal regulation of various family relations can serve as a reference system for national, European and international legislations and significantly facilitate the task of states in regulating cross-border family relations.

Regarding the accepted results, the CEFL believes that this is one of its main tasks in order to identify the criteria on which the choice is based. As a result, principles are developed that are comments or, one might even say, something like arguments about the choice of individual provisions in the content of family normative acts that states need to adopt. The principles of family law are developed by the CEFL on the basis of a comprehensive comparative analysis of international law and EU law. One of the main tasks of the CEFL is to develop, based on the results of this study, general criteria for family law.

As a result, not only the principles were adopted, but a reasoned justification was given why this or that principle was adopted. In fact, the most "best", more "functional" or "effective" rule for regulating certain family relationships is proposed.

\section{CONCLUSIONS}

As a result, the principles of CEFL provide guidance on the development of a strategy aimed at harmonizing family norms, and can serve as the basis for legislators in their efforts to modernize their family laws.

To date, several groups of principles have been developed.

The first group of principles was published in 2004. They are devoted to the legal regulation of divorce, division of property and maintenance relations of former spouses. In its structure, this group of principles consists of two parts: the first part is devoted to divorce, and the second to the procedural issues of property relations of spouses.

The second group of principles is devoted to parental relationships. The first and second areas of activity of CEFL are interconnected and regulate issues that should be resolved in all jurisdictions of the EU countries. The legal institutions governing parental and marital relations have been modernized over the past few decades, taking into account EU regulations and conventions aimed at legal regulation of family cross-border relations.

The third group of principles is devoted to the legal regulation of the matrimonial property regime.

The first and third areas of activity of CEFL are also interrelated, because the problems arising between persons cohabiting with each other are almost identical to the problems arising between spouses (former spouses). 
At the present stage, CEFL efforts will be directed to the legal regulation of new forms of cohabitation, including informal cohabitation. The aim of this stage of activity is to create a European model that is most effective for regulating extramarital cohabitation.

The working language of CEFL is English. Only the black text of the letter of principles is formulated in English, French and German. These different versions are equally valid. Dutch, Spanish and Swedish translations have been added to the respective publications.

CEFL does not limit itself to the development of general principles, but also organizes legal conferences by the family on a regular basis in order to present its results to a wider scientific level ${ }^{11}$. Under the auspices of the CEFL, international conferences on family law are organized. So, the first scientific conference was held on December 11-14, 2002 in Utrecht and was dedicated to the prospects for unification and harmonization of family law in Europe. The second conference again takes place in Utrecht from December 9 to 11,2004 , however, the first steps of integrating European family law as a whole were already discussed at the academic level. The third conference was organized by CEFL in conjunction with the Faculty of Private Law at the University of Oslo in Norway from June 7-9, 2007. Conference proceedings are published in the European journal Family Law (www.intersentia.be).

\section{REFERENCES}

1. Бирюков, М.М. Европейское право: до и после Лиссабонского договора. - М.: Статут, 2013. - 240 c.

2. Будылин, С. Дело Гѐргюлю: Германия выбирает мир с ЕСПЧ. Режим доступа: https://zakon.ru/blog/2013/11/18/_espch.

3. Веняляйнен, М. Медиация и юридическая помощь в трансграничных семейных спорах // Семейное и жилищное право. 2014. - № 1. - C. 33-38.

4. Гармаш, А., Суслова, И. Защита прав детей в Европейском суде // ЭЖ-Юрист. - 2012. - № 31. - С. 15.

5. Косенко, Е.В. Средства и методы научного познания семейного права // Вестник Пермского университета. Юридические науки. - 2015. № 3. - C. 107-116.

6. Международное частное право: учебник: в 2 т. / Е.А. Абросимова, А.В. Асосков, А.В. Банковский и др.; отв. ред. С.Н. Лебедев, Е.В. Кабатова. М.: Статут, 2015. - Т. 2: Особенная часть. - 764 с.

11 Boele-Woelki K. The road towards a european family law / Режим доступа: http://ejcl.org/11/art11-1.html\#N_41_. 
7. Певцова, И.Е. Защита семейной жизни Европейским судом по правам человека / И.Е. Певцов // Юридический мир. - 2014. - № 8. C. $48-52$.

8. Der Schutz der Familienwohnung in europäischen Rechtsordnungen, 1995. Eheliche Gemeinschaft, Partnerschaft und Vermögen im europäischen Vergleich, 1999.

9. Familienerbrecht und Testierfreiheit im europäischen Vergleich, 2001.

10. Guilherme de Oliveira Um direito da família europeu? Europe! in "Um código civil para a Europa". - Coimbra: Coimbra Editora, 2002. P. 117-126.

11. Hofer, S. et al. (eds.) Scheidung und nachehelicher Unterhalt im europäischen Vergleich, 2003.

12.Zechner, M. Informaali hoiva sosiaalipoliittisessa kontekstissa. Acta Universitatis Tamperensis 1543. - Tampere: Tampere University Press, 2010.

13. Boele-Woelki Katharina, The principles of European family law: its aims and prospects: https://www.utrechtlawreview.org/articles/abstract/ 10.18352/ulr.13/.

14. Boele-Woelki, K. The road towards a european family law / BoeleWoelki, Ferrand, González Beilfuss, Jänterä-Jareborg, Lowe, Martiny, Pintens. - Режим доступа: URL: http://ejcl.org/11/art11-1.html\#N_41_.

15. Ackermann/Köndgen (eds.). Familiengründung gleichgeschlechtlicher Paare in Europa. In: Privat-und Wirtschaftsrecht in Europa, Festschrift für Wulf-Henning Roth zum 70. Geburtstag: München 2015. - P. 65-76.

16. Meller-Hannich/Haertlein (eds.). Familienkonflikte vor Gericht Eine rechtsvergleichende Perspektive. In: Rechtslage - Rechtserkenntnis, Rechtsdurchsetzung, Festschrift für Eberhard Schilken zum 70. - Geburtstag: München 2015. - P. 249-259.

17. Boele-Woelki/Dethloff/Gephart (eds.). Family Law and Culture in Europe - Developments, Challenges and Opportunities European Family Series, Bd. 35, Intersentia, 2014.

18. Martiny, D. Is Unification of Family Law Feasible or even Desirable? In: A. Hartkamp et al. (eds.), Towards a European Civil Code, Nijmegen: Ars Aequi Libri, 2011. - P. 429-457.

\section{Information about the author: Hlynynaya K. M., $\mathrm{PhD}$ in Law, Associated} Professor at the Department of Civil Law, National University "Odessa Law Academy" 2, Academychna str., Odessa, 65009, Ukraine 